\title{
PENGUATAN EKONOMI KREATIF BERBASIS POTENSI LOKAL DENGAN MENINGKATKAN JIWA WIRAUSAHA DALAM PEMANFAATAN SUMBER DAYA ALAM DI KELURAHAN MASIRI KECAMATAN BATAUGA KABUPATEN BUTON SELATAN
}

\author{
Nining Asniar Ridzal, Waode Adriani Hasan \\ Program Studi Akuntansi \\ Universitas Muhammadiyah Buton
}

Email: niningasniarrizal84@gmail.com

\begin{abstract}
Abstrak
Kegiatan Pengabdian Kepada Masyarakat ini bertujuan untuk memberikan penyuluhan mengenai ruang lingkup ekonomi kreatif dan bagaimana mengembangkan ide-ide kreatif menjadi sumber-sumber ekonomi kreatif dan Untuk meningkatkan pengetahuan dan pemahaman masyarakat mengenai manfaat ekonomi kreatif dalam meningkatkan kesejahteraan dan perekonomian. Luaran yang diharapkan dari kegiatan ini adalah Masyarakat dapat termotivasi dan lebih percaya diri untuk mengembangkan ide-ide kreatif menjadi sumber-sumber ekonomi kreatif dan Masyarakat memahami pentingnya pengembangan ekonomi kreatif untuk meningkatkan pendapatan dan perekonomian keluarga. Sebagai wujud nyata dari kegiatan pengabdian ini sebagai luarannya adalah dapat membuat atau menghasilkan salah satu produk kreatifitas dari sumber daya alam berupa kerikil menjadi keset kaki terapi, pot dan lain lain. Harapan kami sebagai tim pengabdian pada masyarakat hal ini bisa bermanfaat untuk jangka panjang sehingga mereka sangat memerlukan bimbingan dari pihak-pihak berkompeten.
\end{abstract}

Kata Kunci: Ekonomi Kreatif, Potensi Lokal, Wirausaha

\section{A. Pendahuluan}

Kelurahan Masiri terletak kurang lebih $5 \mathrm{KM}$ dari wilayah kecamatan Batauga kabupaten Buton Selatan, sebagian besar masyarakatnya dihuni oleh suku buton dan sebagian lagi berasal dari suku lain yang telah lama tinggal dan menetap. Posisi Geografisnya adalah sebagai berikut:

a. Sebelah Utara berbatasan dengan Kelurahan laompo

b. Sebelah Timur berbatasan dengan Sampolawa

c. SebelahSelatan berbatasan dengan Kelurahan Majapahit

d. Sebelah Barat berbatasan dengan Laut

Luas wilayah kelurahan masiri adalah 15,33 Ha, terdiri dari Kantor Kelurahan, SDN dan SMAN, Tanah Makam, Pom Bensin, Posyandu, selebihnya merupakan pemukiman dan 
perkebunan warga. Secara umum keadaan topografi Kelurahan Masiri adalah merupakan daerah perbukitan / dataran dataran tinggi.

Berdasarkan Data Administrasi Pemerintah Kelurahan, jumlah penduduk Kelurahan Masiri tercatat $708 \mathrm{KK}$ yang terdiri dari 2.452 jiwa yang tersebar di 7 Dusun yang terdapat 14 RT dan 7 RW, dengan jumlah penduduk laki - laki sebanyak 1.240 jiwa dan perempuan sebanyak 1.212 jiwa (Badan Pusat Statistik Kabupaten Buton, Kecamatan Batauga Dalam Angka Tahun 2019)

Dari hasil pengumpulan data sekunder PKD bila dibandingkan dengan data administrasi Kelurahan, kemungkinan terjadi perbedaan yang disebabkan telah berpindahnya domisili sebagian penduduk untuk mencari pekerjaan di daerah lain dan juga adanya pendatang baru yang belum terdata sebagai penduduk.

Kegiatan Ekonomi Desa selama ini masih didominasi oleh sektor industri bahan bangunan, pembuatan meubel dan banyaknya usaha penambangan / galian batu. Berdasarkan data dari Badan Pusat Statistik pada tahun 2018 di Kelurahan Masiri terdapat 3 (tiga) Industri Bahan Bangunan (pembuatan batubata), 6 (enam) Industri Perabot dan Perlengkapan Rumah Tangga yang terbuat dari kayu dan 38 Usaha Penambangan / Penggalian batu atau koral.

Tingkat pendapatan masyarakat belum seutuhnya mencukupi kebutuhan hidup karena harga barang tidak sebanding dengan pengahasilan yang didapat mereka serta masih bekal keterampilan upah buruh yang masih kecil serta masih mahalnya barang-barang kebutuhan sembako. Keadaan tersebut tidak hanya terjadi di wilayah kelurahan masiri namun wilayah lain juga keadaanya hampir sama.

a. Pertumbuhan Ekonomi

Pertumbuhan perekonomian masih didominasi oleh bahan bangunan dan pertambangan yang digeluti oleh sebagian besar masyarakat kelurahan masiri, dalam Data Profil Kelurahan Tahun 2019 disebutkan bahwa:
a) Potensi Umum
: sedang
b) Potensi sumber daya alam
: sedang
c) Potensi Sumber daya manusia
: sedang
d) Potensi Kelembagaan
: Baik
e) Potensi sarana dan prasarana
: sedang

Dari tingkat pertumbuhan ekonomi diatas khususnya dibidang Pertambangan perlu 
dikelola secara Profesional dengan mengandalkan sistem pemasaran yang memadai, yang bisa menampung seluruh hasil pertanian dan perikanan diwilayah tersebut, karena kendala selama ini adalah masalah yang kurang baik/harga jual yang rendah.

Selain itu penyebab belum berkembangnya potensi dan sumber daya ekonomi kreatif di Kelurahan Masiri adalah karena belum terbangunnya struktur industri yang menopang pengembangan ekonomi kreatif dan belum tersedianya skema pembiayaan bagi pelaku industri ekonomi kreatif. Kondisi tersebut diikuti dengan terbatasnya akses pemasaran ekonomi kreatif dan belum optimalnya support kelembagaan ekonomi kreatif (sinergitas pemerintah, komunitas kreatif, dunia usaha dan akademisi). Beberapa permasalahan tersebut disebabkan karena belum optimalnya model kebijakan yang terintegrasi dalam mendukung pengembangan ekonomi kreatif di Kelurahan Masiri Kabupaten Buton Selatan.

Ekonomi kreatif sendiri merupakan konsep ekonomi baru yang memadukan informasi dan kreatifitas yang mengandalkan ide, gagasan, dan pengetahuan dari sumber daya manusia sebagai faktor produksi (Gusti Bagus Arjana, 2016).

Ekonomi kreatif di Indonesia saat ini mulai tumbuh dan berkembang menjadi sektor ekonomi yang memiliki peranan penting bagi perekonomian. Pada tahun 2014, ekonomi kreatif diperkirakan telah berkontribusi sebesar 7,1\% terhadap PDB nasional, menyediakan 12 juta tenaga kerja, dan memberikan kontribusi perolehan devisa negara sebesar 5,8\%. Dalam lima tahun ke depan, sektor ini ditargetkan memiliki kontribusi terhadap PDB nasional mencapai 12\%, 13 juta tenaga kerja, dan kontribusi ekspor mencapai 10\% (https://ekon.go.id/berita/print/pengembangan-kota-kreatif.1715.html)

Perkembangan ilmu pengetahuan dan teknologi telah mampu mengubah cara pandang, pola pikir, dan pola kehidupan manusia serta mampu mendorong terciptanya penemuanpenemuan yang dapat menghambat kelangkaan barang dan jasa. Melalui inovasi, riset, pengembangan yang terus-menerus tercipta produk barang dan jasa apa saja yang diinginkan dan dibutuhkan oleh konsumen. Dampaknya mengubah pola kehidupan ekonomi masyarakat secara global dalam berbagai bidang, seperti pola produksi, pola distribusi, dan pola konsumsi. dan menimbulkan pola kebutuhan dan pola konsumsi masyarakat yang terangsang oleh terciptanya produk-produk baru. Perubahan-perubahan orientasi tersebut oleh Howkins dikenal dengan "gelombang ekonomi", dan sekarang memasuki gelombang ekonomi ke empat, yaitu gelombang ekonomi kreatif (Suryana: 2013). John Howkins dalam bukunya The Creative Economy: How People Make Money pertama kali memperkenalkan istilah 
ekonomi kreatif. Howkins menyadari lahirnya gelombang ekonomi baru berbasis kreativitas setelah melihat pada tahun 1997, ekonomi kreatif sebagai "kegiatan ekonomi dalam masyarakat yang menghabiskan sebagian besar waktunya untuk menghasilkan ide, tidak hanya melakukan hal-hal yang rutin dan berulang. Ekonomi kreatif adalah penciptaan nilai tambah yang berbasis ide yang lahir dari kreativitas sumber daya manusia (orang kreatif) dan berbasis pemanfaatan ilmu pengetahuan, termasuk warisan budaya dan teknologi. Lebih lanjut didevinisikan Ekonomi kreatif atau dikenal juga dengan sebutan knowledge based economy merupakan pendekatan dan tren perkembangan ekonomi dimana teknologi dan ilmu pengetahuan memiliki peran penting di dalam proses pengembangan dan pertumbuhan ekonomi. Ekonomi kreatif dapat diartikan sebagai kumpulan aktivitas ekonomi yang terkait dengan penciptaan atau penggunaan pengetahuan dan informasi. Definisi menurut Institute ForDevelopment Economy and Finace (2005), ekonomi kreatif merupakan proses peningkatan nilai tambah hasil dari eksploitasi kekayaan intelektual berupa kreativitas, keahlihan, dan bakat individu menjadi sautu produk yang dapat dijual. Dari beberapa definisi di atas dapat diartikan bahwa ekonomi kreatif adalah sebuah kegiatan ekonomi yang timbul dari adanya kreatifitas, di mana dari berbagai kreatifitas, inovasi, bakat, ide, gagasan, sebagai wujud nyata dari kreatif tersebut dan kekayaan intelektual merupakan sumber utama dari ekonomi kreatif.

Secara keseluruhan industri kreatif terbukti memainkan peran yang signifikan bagi perekonomian nasional dengan memberikan kontribusi yang cukup besar terhadap pendapatan domestik bruto ratarata sekitar 7,1\% dari PDB. Ekonomi Kreatif Berbasis Seni dan Budaya pada tahun 2013 mampu menyerap tenaga kerja sebanyak 7,06 juta orang atau sebesar 59,4\% dari total penyerapan tenaga kerja sektor industri nasional. Penyerapan tenaga kerja ekonomi kreatif Seni dan Budaya didominasi oleh kelompok industri kuliner dan kerajinan. Untuk pertumbuhan produktivitas tenaga kerja di sektor Ekonomi Kreatif Berbasis Seni dan Budaya tumbuh sebesar 0,53\% pada tahun 2013 (Kemenparekraf, 2014).

Dalam buku "Pengembangan ekonomi kreatif Indonesia 2025: Rencana pengembangan ekonomi kreatif Indonesia 2009-2015”, yang diterbitkan oleh Departemen Perdagangan RI, dikatakan bahwa "Pengembangan ekonomi kreatif Indonesia tidak hanya menekankan pada pengembangan industri yang termasuk dalam kelompok industri kreatif nasiaonal, melainkan juga pada pengembangan berbagai faktor yang signifikan perannya dalam ekonomi kreatif, yaitu sumber daya insani, bahan baku, teknologi, tatanan institusi dan lembaga pembiayaan 
yang menjadi komponen dalam model pengembangan." Dari kalimat tersebut dapat disimpulkan bahwa pengembangan industri di Indonesia membutuhkan dukungan sekurangnya empat pilar utama yaitu ketersediaan bahan baku (resources), infrastruktur dan teknologi, sumber daya manusia (SDM) yang siap pakai, serta lembaga-lembaga keuangan (financial institutions).

Depdag (2007) menyusun sebuah rancangan pengembangan dalam menghadapi persaingan dalam bidang ekonomi kreatif yang terbagi menjadi 14 sektor yaitu periklanan, arsitektur, pasar barang seni, kerajinan, desain,fashion, film-video dan fotografi, permainan interaktif, musik, seni pertunjukan, penerbitan dan percetakan, layanan komputer, radio dan televise (Simatupang, 2008). Dalam perkembangannya, ada penambahan beberapa sector industri sebagai inkubator industri kreatif, yaitu agrobisnis, kuliner, dan otomotif (Murniati, 2009). Dalam pelaksanaannya industri kecil dan menengah banyak mendominasi dan menggerakkan industry kreatif (Murniati, 2009)

Sumber daya yang melimpah baik sumber daya manusia, sumber daya alam dan sumber daya budaya yang dimiliki memberikan peluang besar bagi berkembangnya ekonomi kreatif di indonesia. Salah satu bentuk kreativitas bisa melalui kewirausahaan. Kewirausahaan adalah kemampuan kreatif dan inovatif yang dijadikan dasar, kiat, dan sumber daya untuk mencari peluang sukses. Memiliki jiwa entrepreneur berarti mendorong adanya mental yang mandiri, kreatif, inovatif, bertanggung jawab, disiplin, dan tidak mudah menyerah, seperti layaknya seorang wirausaha ketika memulai usahanya dari bawah. Alangkah baiknya jika sifat-sifat ini ditelurkan pada generasi muda yang notabene adalah jiwa petualang, penuh ide, dan menyukai tantangan secara umum memiliki kesamaan dengan konsep wirausaha yang menjawab tantangan dan memanfaatkan peluang. Dush M. Dkk. (2012) di Orissa, India menemukan bahwa kewirausahaan oleh kaum muda dalam beberapa tahun terakhir telah berhasil mendongkrak persaingan ekonomi dan meningkatkan pembangunan di daerah tersebut. Kewirausahaan di kalangan kaum muda jarang dieksplorasi secara khusus, bahkan kebijakan dan program seringkali dibuat satu namun berlaku untuk semua (one size fits all). Bisnis tak lagi identik dengan suatu usaha yang dijalankan oleh mereka yang berusia matang dengan segenap kemampuan dan skill pendukung dalam mendirikan sebuah bisnis. Anak muda khususnya kaum mahasiswa dengan rentang usia antara 18-25 tahun telah banyak yang menjadi pebisnis muda atau pengusaha muda atau lebih dikenal dengan istilah young entrepreneurship. 
Kewirausahaan merupakan kemampuan dalam menciptakan sesuatu yang baru dan berbeda. Pengertian ini mengandung maksud bahwa seorang wirausahan adalah orang yang memiliki kemampuan untuk menciptakan sesuatu yang baru, berbeda dari yang lain. Atau mampu menciptakan sesuatu yang berbeda dengan yang sudah ada sebelumnya (Drucker dalam Winardi, 2003). Menurut Kasmir (2007) kewirausahaan sebagai suatu proses penerapan kreativitas dan inovasi dalam memecahkan persoalan dan menemukan peluang untuk memperbaiki kehidupan (usaha). Salah satu kesimpulan yang bisa ditarik dari berbagai pengertian tersebut adalah bahwa kewirausahaan dipandang sebagai fungsi yang mencakup eksploitasi peluangpeluang yang muncul di pasar. Eksploitasi tersebut sebagian besar berhubungan dengan pengarahan dan atau kombinasi input yang produktif.

\section{B. Masalah}

Berdasarkan latarbelakang di atas pengabdi merumuskan masalah sebagai berikut;

1. Bagaimana mengembangkan ide-ide kreatif menjadi sumber-sumber ekonomi kreatif?

2. Bagaimana meningkatkan pengetahuan dan pemahaman masyarakat mengenai manfaat ekonomi kreatif dalam meningkatkan kesejahteraan dan perekonomian.

\section{Metode Pelaksanaan}

Sasaran dari kegiatan ini adalah warga masyarakat Kelurahan Masiri Kecamatan Batauga Kabupaten Buton Selatan yang berminat terhadap pengembangan ekonomi kreatif di kelurahan sebanyak 40 (Empat Puluh) Orang.

Luaran yang diharapkan dari kegiatan ini adalah: 1. Masyarakat dapat termotivasi dan lebih percaya diri untuk mengembangkan ide-ide kreatif menjadi sumber-sumber ekonomi kreatif. 2. Masyarakat memahami pentingnya pengembangan ekonomi kreatif untuk meningkatkan pendapatan dan perekonomian keluarga.

Kegiatan pengabdian kepada masyarakat ini akan dilaksanakan di Kelurahan Masiri Kecamatan Batauga Kabupaten Buton Selatan. Pelaksanaan pengabdian kepada masyarakat ini dilakukan selama 1 (satu) bulan yang terdiri dari beberapa tahapan sebagai berikut:

1. Mempersiapkan bahan atau materi yang diperlukan pada penyuluhan Penguatan Ekonomi Kreatif Berbasis Potensi Lokal Dengan Meningkatkan Jiwa Wirausaha Perempuan Dalam Pemanfaatan Sumber Daya Alam Di Kelurahan Masiri Kecamatan Batauga Kabupaten Buton Selatan.

2. Mengadakan pertemuan dengan Lurah Kelurahan Masiri Kecamatan Batauga Kabupaten Buton Selatan guna mendapatkan izin pelaksanaan dan penetapan jadwal kegiatan. 
3. Melakssanakan penyuluhan Penguatan Ekonomi Kreatif Berbasis Potensi Lokal Dengan Meningkatkan Jiwa Wirausaha Perempuan Dalam Pemanfaatan Sumber Daya Alam Di Kelurahan Masiri Kecamatan Batauga Kabupaten Buton Selatan.

\section{Pembahasan}

Kegiatan pengabdian ini terselenggara atas kerjasama dengan masyarakat kelurahan Masiri Kecamatan Batauga Kabupaten Buton Selatan. beserta seluruh mahasiswa Kuliah Kerja Amaliyah (KKA) Universitas Muhammadiyah Buton Tahun 2019. Kegiatan penyuluhan ini merupakan salah satu tahapan penting dari kegiatan pengabdian kepada masyarakat sebagai bagian Caturdarma Perguruan Tinggi yang dilaksanakan pada tanggal 12 September 2019 mulai jam 13.00 WIB hingga selesai. Penyuluhan dilakukan di Aula Kantor Lurah kelurahan Masiri Kecamatan Batauga Kabupaten Buton Selatan. Yang memberi kata sambutan dalam penyuluhan ini adalah Lurah Masiri Kecamatan Batauga Kabupaten Buton Selatan. Dalam pelaksanaannya kegiatan penyuluhan ini dihadiri oleh berbagai lapisan masyarakat. Tokoh masyarakat yang hadir antara lain Bapak Lurah Masiri, beserta seluruh RT dan RW serta mahasiswa Kuliah Kerja Amaliah. Masyarakat yang hadir tampak sangat antusias mendengarkan penyuluhan yang disampaikan, hal ini tampak dari banyaknya masyarakat yang bertanya dan ingin mendapatkan penjelasan lebih mendalam bagaimana ekonomi kreatif bisa mereka kembangkan diwilayah mereka.

Sebagai wujud nyata dari kegiatan pengabdian ini sebagai luarannya adalah dapat membuat atau menghasilkan salah satu produk kreatifitas dari sumber daya alam berupa kerikil menjadi keset kaki terapi, pot dan lain lain. Harapan kami sebagai tim pengabdian pada masyarakat hal ini bisa bermanfaat untuk jangka panjang sehingga mereka sangat memerlukan bimbingan dari pihak-pihak berkompeten. Kegiatan penyuluhan dilakukan dengan metode ceramah, tanya jawab serta mempertontonkan video proses-proses pembuatan produk kreatif masyarakat pedesaan dari daerah lain. Pemutaran video ini juga bermaksud untuk memotivasi keinginan masyarakat untuk mengembangkan ide-ide kreatif yang dimiliki untuk memanfaatkan sumber daya yang tersedia diwilayahnya. Potensi sumberdaya desa Kelurahan Masiri beragam dan prospek dikembangkan untuk mendukung ekonomi kreatif masyarakat. Sumberdaya yang dapat mendukung ekonomi kreatif masyarakat antara lain sumber daya alam (pasir, kerikil), sumberdaya pertanian (kelapa, bawang merah), sumber daya perikanan (udang, ikan dan lain-lain), wisata (pantai, dan lain-lain), Di sini memiliki tempat yang sangat menarik untuk dikembangkan sebagai upaya meningkatkan 
kesejahteraan. Sumberdaya yang terpenting yang dimiliki adalah sumberdaya insani yang dimiliki desa untuk pengembangan ekonomi kreatif. Karena itu substansi isi materi penyuluhan yang disampaikan disesuaikan dengan potensi sumberdaya yang ada di Kelurahan Masiri. Materi penyuluhannya antara lain mengenai pemahaman apa yang dimaksud dengan ekonomi kreatif, apa itu kreatifitas, bagaimana proses pembuatan produk kreatif (dalam hal ini produk berbahan dasar batu kerikil), Selain dengan metode ceramah materi juga disampaikan dengan pemutaran video film proses pembuatan produk olahan kreatif tersebut. Sehingga masyarakat menjadi lebih cepat pemahamannya dan tertarik mengikuti penyuluhan hingga selesai. Melalui penyuluhan, masyarakat mendapatkan informasi dan wawasan, sehingga masyarakat dapat memahami secara mendalam tentang ekonomi kreatif serta manfaatnya bagi peningkatan pendapatannya. Dalam Kegiatan ini tampak dari aktifitas masyarakat setempat, dengan mudah menerima pengetahuan baru dan berkeinginan mengimplementasikannya. Namun untuk memperoleh hasil yang lebih maksimal hal yang dapat dilakukan adalah diperlukan kegiatan lanjutan yang bersifat pendampingan masyarakat sehingga mereka terus bisa menekuni usaha yang akan dibuat.

Selanjutnya masyarakat dapat memanfaatkan fenomena ekonomi digital ternyata sudah berjalan dengan baik karena sebagian besar pelaku usaha sudah menggunakan media sosial sebagai alat promosi.

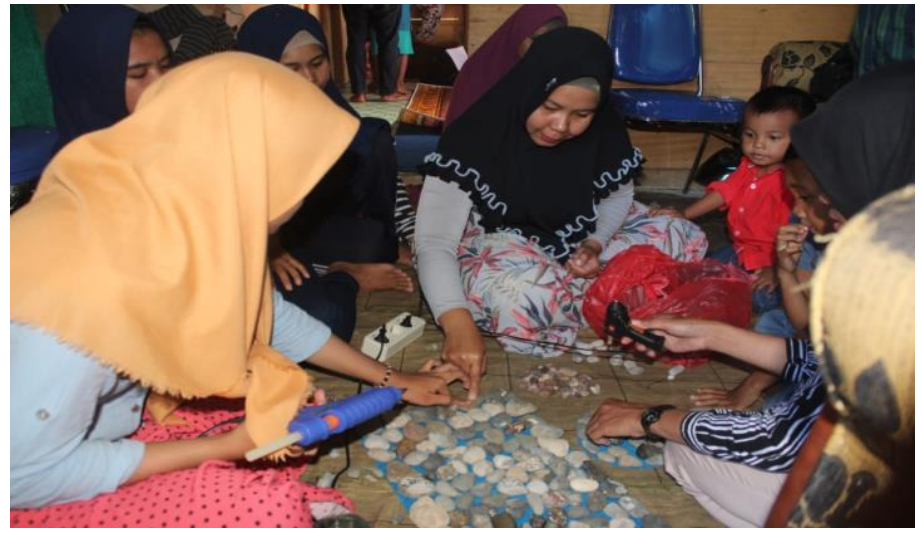



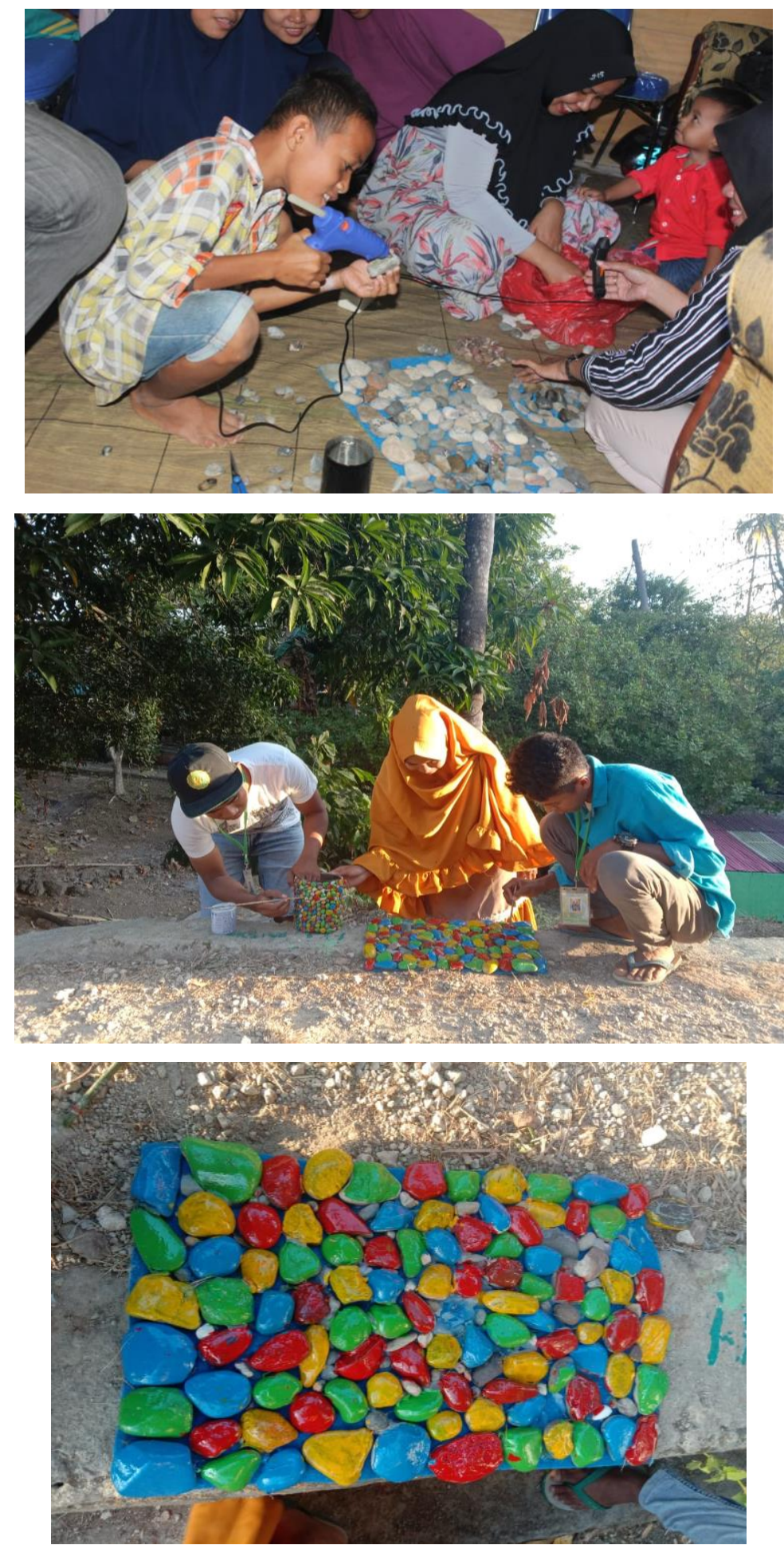


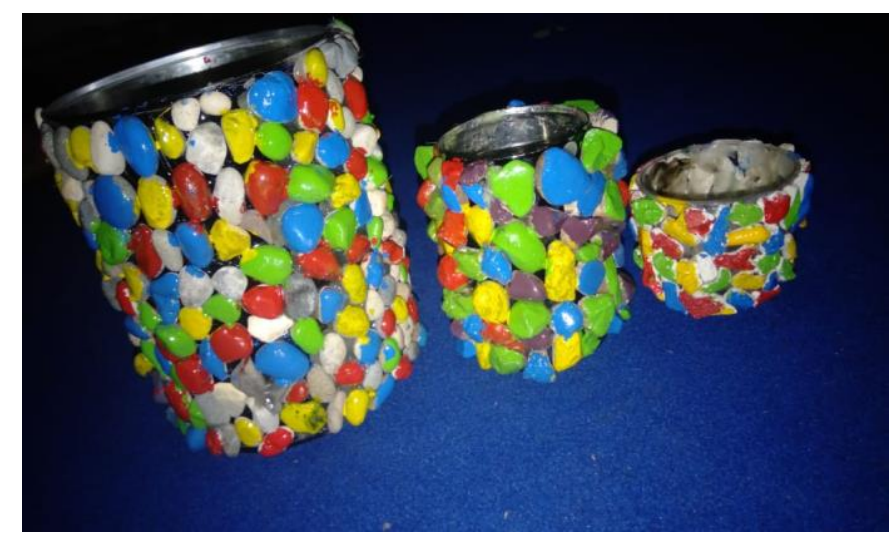

Gambar 1. Hasil Kereatifitas Masyarakat

\section{E. Kesimpulan}

Kegiatan penyuluhan Penguatan Ekonomi Kreatif Berbasis Potensi Lokal Dengan Meningkatkan Jiwa Wirausaha dalam Pemanfaatan Sumber Daya Alam di Kelurahan Masiri Kecamatan Batauga Kabupaten Buton Selatan memberi manfaat bagi masyarakat. Ini tampak dari antusiasnya masyarakat dalam tanya jawab dan termotivasi mengembangkan kreatifitas usahanya. Sehingga kegiatan ini perlu dilakukan secara berkelanjutan.

\section{DAFTAR PUSTAKA}

Badan Pusat Statistik Kabupaten Buton: Kecamatan Batauga Dalam Angka Tahun 2019 : ISBN: 0852 - 7709 No. Publikasi / Publication Number: 74150.1804 Katalog / Catalog: 1102001.7415040

Suryana. (2013). Ekonomi Kreatif, Ekonomi Baru: Mengubah Ide dan Menciptakan Peluang, Jakarta: Salemba Empat.

Gusti Bagus Arjana, (2016) Geografi Pariwisata dan Ekonomi Kreatif, Jakarta: Rajawali Pers.

Dash, M. and Kulveen Kaur (2012).Youth Entrepreneurship as a Way of Boosting Indian Economic Competitiveness: A Study of Orissa. India: International Review of Management and Marketing, Vol 2 No 1

Murniati, D.E. (2009). Peran Perguruan Tinggi Dalam Triple Helix Sebagai Upaya Pengembangan Industri Kreatif. Seminar Nasional Peran Pendidikan Kejuruan Dalam Pengembangan Industri Kreatif. Jurusan PTBB FT UNY

Simatupang dkk, (2008). Analisis Kebijakan Pengembangan Industri Kreatif di Kota Bandung. Jurnal Manajemen Teknologi, Volume 8 Number 1.

Winardi. (2003). Entrepreneur dan Entrepreneurship. Jakarta: Kencana.

Kasmir. (2007) Kewirausahaan. Jakarta: PT Raja Grafindo Perkasa 